Artikel Penelitian

\title{
Perbandingan Profil Penderita Tuberkulosis Paru antara Perokok dan Non Perokok di Poliklinik Paru RSUP. Dr. M. Djamil Padang
}

Cantika Dinia Zulda ${ }^{1}$, Rizanda Machmud ${ }^{2}$, Irvan Medison ${ }^{3}$

\begin{abstract}
Abstrak
Tuberkulosis (TB) merupakan masalah kesehatan masyarakat yang penting di dunia, terutama di negara berkembang seperti Indonesia. Salah satu faktor risiko yang dapat menurunkan daya tahan tubuh terhadap bakteri Mycobacterium tuberculosis adalah faktor merokok. Menurut Public Health Agency of Canada terdapat hubungan yang erat antara merokok dengan TB. Tujuan penelitian ini bertujuan adalah menentukan perbandingan profil penderita TB paru antara perokok dan non perokok di Poliklinik Paru RSUP Dr. M. Djamil Padang. Desain yang digunakan adalah cross sectional komparatif terhadap 44 penderita TB perokok dan 44 penderita TB non perokok. Data dikumpulkan melalui wawancara dan rekam medis. Hasil uji statistik menunjukkan terdapat perbedaan yang bermakna antara penderita TB paru perokok dan non perokok berdasarkan hasil pemeriksaan BTA awal $(p=0,012)$ dan gejala hemoptisis $(p=0,002)$. Uji statistik pada rata-rata usia $(p=0,109)$, kejadian TB relaps $(p=0,244)$ dan adanya komplikasi $(p=0,395)$ menunjukkan tidak ada perbedaan yang bermakna antara penderita TB perokok dan non perokok.
\end{abstract}

Kata kunci: tuberkulosis paru, profil, perokok

\section{Abstract}

Tuberculosis is an important public health problem in the world, exactly in developing countries like Indonesia. One of the risk factors that can lower the body's resistance to Mycobacterium tuberculosis is a smoking. Based on the report of the Public Health Agency of Canada there is relationship between smoking and TB. The objective of this study was to determine the differentiation of the lung TB profiles between smoker and non- smoker patients at Pulmonary Clinic RSUP Dr. M. Djamil Padang. The research was done at Pulmonary Clinic RSUP Dr. M. Djamil Padang, in using cross sectional study comparative's design toward 44 smoker TB patients and 44 non-smoker TB patients. Data was collected from direct interviews and medical records. Statistic result showed that there are significant differentiation between the smoker and non-smoker lung tuberculosis patients based on the results of the sputum specimens examination ( $p$ value: 0,012) and symptoms of hemoptysis ( $p$ value: 0,002$)$. Whereas, based on average age ( $p$ value: 0,109$)$, incident of TB relaps ( $p$ value: 0,244$)$ and complications ( $p$ value: 0,395$)$, showed no significant differentiation between the smoker patients and non-smokers patients.

Keywords: lung tuberculosis, profiles, smokers

Affiliasi penulis: 1. Prodi Profesi Dokter FK Unand (Faklutas Kedokteran Universitas Andalas Padang 2: Bagian Kesehatan Masyarakat FK Unand, 3: Bagian Paru FK Unand.

Korespondensi: Cantika Dinia Zulda, Email:

cantikadiniaz21@gmail.com, Telp/Hp: 085274656910

\section{PENDAHULUAN}

Tuberkulosis (TB) merupakan masalah kesehatan dunia yang penting karena lebih kurang sepertiga penduduk dunia pernah terinfeksi oleh Mycobacterium tuberculosis. ${ }^{1,2}$ Sebagian besar dari kasus TB dan kematiannya terjadi di negara - negara 
yang sedang berkembang. Alasan utama muncul atau meningkatnya beban TB global ini antara lain disebabkan perlindungan kesehatan yang tidak mencukupi pada penduduk di kelompok yang rentan terutama di negara-negara berkembang. ${ }^{3}$ Salah satu faktor yang dapat menurunkan daya tahan tubuh terhadap bakteri Mycobacterium tuberculosis adalah faktor merokok. ${ }^{4}$ Merokok akan menyebabkan seseorang mudah terinfeksi bakteri TB dan berkembang menjadi TB aktif. Merokok juga akan memperburuk TB dengan merusak mekanisme pertahanan "muccociliary clearance". ${ }^{5}$

Negara dengan angka TB yang tinggi, Indonesia juga termasuk dalam "high burden countries" di bidang rokok bersama dengan empat negara lain yaitu Cina, India, Rusia dan Bangladesh. Indonesia menduduki peringkat kelima dalam konsumsi rokok dunia serta peringkat ketujuh dalam penghasil tembakau. ${ }^{6}$

Pada tahun 2011, Indonesia termasuk dalam lima besar negara dengan angka kejadian TB tertinggi di dunia. Indonesia menduduki peringkat ke empat setelah India, Cina dan Afrika Selatan. ${ }^{7}$ Menurut data Kemenkes RI, pada tahun 2011 ditemukan sekitar 6691 kasus TB di Sumatera Barat. ${ }^{8}$

Data Riskesdas 2010 menunjukkan prevalensi penduduk umur 15 tahun ke atas yang merokok tiap hari secara nasional adalah $28,2 \%$. Sumatera Barat termasuk dalam 5 provinsi tertinggi dalam prevalensi merokok tiap hari yaitu $33,1 \%{ }^{9}$

Menurut Public Health Agency of Canada dan Schluger, terdapat hubungan yang erat antara merokok dengan TB. ${ }^{10,11}$ Penelitian yang dilakukan Wang tahun 2009 seperti yang dikutip Hudoyo (2013) pada kelompok perokok dan non perokok didapatkan proporsi penderita TB lebih banyak pada kelompok perokok. ${ }^{12}$ Beberapa penelitian juga menunjukkan terdapat perbedaan gambaran penyakit TB antara perokok dan non perokok. Pada perokok ditemukan gejala penyakit dan kerusakan paru yang lebih berat dibandingkan non perokok. ${ }^{13}$ Tujuan dari penelitian ini adalah untuk mengetahui perbandingan profil penderita TB paru antara perokok dan non-perokok di Poliklinik Paru RSUP. Dr. M. Djamil Padang.

\section{METODE}

Jenis studi ini adalah analitik observasional dengan desain cross sectional. Populasi penelitian adalah semua pasien TB paru yang datang berobat ke Poliklinik Paru RSUP Dr. M. Djamil Padang pada periode 15 September 2013-31 Januari 2014. Kriteria inklusi adalah penderita TB paru dengan diagnosis TB Paru BTA (+) dan TB Paru BTA (-) rontgen (+) yang berobat ke Poliklinik Paru RSUP Dr. M. Djamil Padang periode 15 September 2013 - 31 Januari 2014 dan bersedia untuk diwawancarai. Kriteria Eksklusi adalah penderita TB paru dengan data pengisian status yang tidak lengkap. Variabel dependen dalam penelitian ini terdiri dari rata-rata usia, hasil BTA awal, gejala hemoptisis, kejadian TB relaps dan adanya komplikasi. Variabel independen yaitu riwayat merokok.

Analisis data penelitian terdiri dari analisis univariat dan bivariat. Analisis bivariat bertujuan untuk melihat ada atau tidaknya perbedaan yang bermakna profil penderita TB paru antara perokok dan non perokok.

\section{HASIL}

Penelitian ini memperlihatkan perbandingan profil penderita TB antara perokok dan tidak perokok berdasarkan hasil pemeriksaan BTA awal dan adanya gejala hemoptisis 
Tabel 1. Perbandingan profil penderita tuberkulosis paru antara perokok dan non perokok di poliklinik paru RSUP. Dr. M. Djamil Padang

\begin{tabular}{|c|c|c|c|}
\hline \multirow[t]{2}{*}{ Profil } & \multicolumn{2}{|c|}{ Nilai } & \multirow[b]{2}{*}{$\mathbf{P}$} \\
\hline & Perokok & $\begin{array}{c}\text { Non } \\
\text { perokok }\end{array}$ & \\
\hline \multicolumn{4}{|l|}{ Usia } \\
\hline Rata-rata usia & 44,07 & 38,18 & 0,109 \\
\hline Range & 19,79 & $14-75$ & \\
\hline Usia $\leq 20$ & $5(11,4 \%)$ & $7(15,9 \%)$ & \\
\hline Usia 21-40 & $17(38,6 \%)$ & $18(40,9 \%)$ & \\
\hline Usia 41-60 & $13(29,5 \%)$ & $14(31,8 \%)$ & \\
\hline Usia $\geq 61$ & $9(20,5 \%)$ & $5(11,4 \%)$ & \\
\hline \multicolumn{4}{|c|}{ Hasil pemeriksaan } \\
\hline \multicolumn{4}{|l|}{ BTA awal } \\
\hline Negatif & $15(34,1 \%)$ & $24(54,5 \%)$ & 0,012 \\
\hline Positif 1 & $8(18,2 \%)$ & $13(29,5 \%)$ & \\
\hline Positif 2 & $16(36,4 \%)$ & $6(13,6 \%)$ & \\
\hline Positif 3 & $5(11,4 \%)$ & $1(2,3 \%)$ & \\
\hline \multicolumn{4}{|c|}{ Gejala hemoptisis } \\
\hline Ada & $23(52,3 \%)$ & $9(20,5 \%)$ & 0,002 \\
\hline Tidak ada & $21(47,7 \%)$ & $35(79,5 \%)$ & \\
\hline \multicolumn{4}{|c|}{ Komplikasi pada } \\
\hline \multicolumn{4}{|c|}{ awal pengobatan } \\
\hline Ada & $9(20,5 \%)$ & $6(13,6 \%)$ & 0,395 \\
\hline Tidak ada & $35(79,5 \%)$ & $38(86,4 \%)$ & \\
\hline \multicolumn{4}{|l|}{ TB relaps } \\
\hline Ada & $9(20,5 \%)$ & $5(11,4 \%)$ & 0,244 \\
\hline Tidak ada & $35(79,5 \%)$ & $39(88,6 \%)$ & \\
\hline
\end{tabular}

Tabel 1 memperlihatkan hasil uji statistik yang menunjukan terdapat perbedaan yag bermakna antara penderita TB paru perokok dan non perokok berdasarkan hasil pemeriksaan BTA awal dan adanya gejala hemoptisis $(p<0,05)$ serta tidak terdapat perbedaan yang bermakna antara penderita TB paru perokok dan non perokok berdasarkan rata-rata usia, kejadian TB relaps dan adanya komplikasi $(p>0,05)$.

\section{PEMBAHASAN}

Berdasarkan hasil penelitian, pada penderita TB perokok didapatkan usia rata-rata 44,07 , lebih tua dari kelompok penderita TB non perokok. Hasil uji-t tidak didapatkan perbedaan yang bermakna antara rata-rata usia penderita TB paru perokok dan non perokok dengan nilai $\mathrm{P}=0,109 \quad(p>0,05)$. Hasil penelitian ini berbeda dengan penelitian yang dilakukan Muhammad Zainul di Klinik Jemadi Medan yang menemukan penderita TB perokok paling banyak berada pada kelompok usia yang lebih muda dari pada penderita non perokok. ${ }^{14}$ Perbedaan ini dapat terjadi disebabkan oleh perbedaan tempat, populasi penelitian dan adanya faktor resiko lainnya yang dapat mempengaruhi kejadian penyakit TB, seperti malnutrisi, lingkungan tempat tinggal dan lain - lain.

Berdasarkan hasil pemeriksaan BTA awal, pada penderita TB perokok didapatkan hasil pemeriksaan terbanyak adalah BTA positif 2 sebanyak $36,4 \%$. Pada penderita TB non perokok didapatkan hasil pemeriksaan terbanyak adalah BTA negatif sebanyak $54,5 \%$. Hasil uji statistik dengan chi-square didapatkan perbedaan yang bermakna antara penderita TB paru perokok dan non perokok berdasarkan hasil pemeriksaan BTA awal dengan nilai $p=0,012(p<0,05)$.

Merokok akan memperburuk TB dengan merusak mekanisme pertahanan "muccociliary clearance". Silia yang telah rusak karena asap rokok tidak mudah membuang infeksi yang sudah masuk di paru. Rokok akan mengganggu mekanisme pertahanan alamiah yang dimediasi oleh makrofag, sel epitel, sel dendritic (DCs), dan sel natural killer (NK). Pertahanan mukosa yang terganggu dapat mengakibatkan kolonisasi bakteri. ${ }^{5}$

Berdasarkan gejala klinis yang timbul, ditemukan sebanyak $52,3 \%$ dari penderita TB perokok yang mengalami hemoptisis (batuk darah), di mana kejadiannya lebih banyak daripada penderita TB non perokok yang hanya ditemukan sebanyak 20,5\%. Hasil uji statistik dengan chi-square didapatkan $p=0,002 \quad(p<0,05) \quad$ sehingga disimpulkan terdapat perbedaan yang bermakna antara penderita TB paru perokok dan non perokok berdasarkan ada atau tidaknya gejala hemoptisis pada awal pengobatan. Hasil penelitian ini serupa dengan penelitian yang pernah dilakukan oleh Fekih dari tahun 2006 sampai 2008, yang juga menemukan hemoptisis lebih sering terjadi pada perokok dibandingkan non perokok. ${ }^{15}$ Penelitian Hudoyo et al dan Isa juga menemukan bahwa pada perokok lebih sering terjadi kavitas. ${ }^{12,16}$ Terjadinya hemoptisis (batuk darah) bisa disebabkan oleh ekskavasi dan ulserasi dari pembuluh darah pada dinding kavitas. ${ }^{17}$

Komplikasi pada penderita TB paru di Poliklinik Paru RSUP. Dr. M. Djamil Padang, ditemukan sebanyak 20,5\% penderita TB paru perokok yang 
mengalami komplikasi pada awal pengobatan yang terdiri dari $18,2 \%$ mengalami komplikasi berupa efusi pleura dan 2,3\% mengalami pleuritis. Pada penderita TB non perokok ditemukan hanya 13,6\% yang mengalami gejala komplikasi yang terdiri dari $6,8 \%$ mengalami efusi pleura dan $6,8 \%$ mengalami pleuritis. Penelitian Hudoyo et al dan Isa juga menyatakan pada perokok biasanya derajat penyakit lebih berat dibandingkan dengan bukan perokok. Pada perokok ditemukan juga progress dan prognosis dari infeksi lebih buruk. ${ }^{12,16}$ Penelitian yang dilakukan oleh Loh et al tentang efusi pleura pada pasien TB, juga didapatkan riwayat merokok sebagai salah satu faktor yang berperan dalam menghambat penyembuhan secara komplit. ${ }^{18}$

Hasil uji statistik dengan chi-square didapatkan $p=0,395 \quad(p>0,05)$, berarti tdak terdapat perbedaan yang bermakna antara penderita TB perokok dan non perokok berdasarkan ada atau tidaknya komplikasi pada awal pengobatan. Hal ini bisa terjadi karena selain faktor merokok, ada beberapa faktor lain yang juga berperan dalam terjadinya komplikasi seperti keterlambatan diagnosis dan pengobatan. Jika diagnosis dan pengobatan TB terlambat, bakteri bisa berkembang biak dalam paru dan bisa menyebar ke organ lain. $^{19}$

Berdasarkan kejadian TB relaps, diketahui bahwa sebanyak 20,5\% penderita TB perokok di Poliklinik Paru RSUP Dr. M. Djamil Padang merupakan kasus TB relaps, lebih banyak dari pada kelompok non perokok yang hanya ditemukan sebanyak $11,4 \%$. Hasil uji chi-square didapatkan $P=0,244 \quad(P>0,05)$, di mana disimpulkan bahwa tidak terdapat perbedaan yang bermakna antara penderita TB perokok dan non perokok berdasarkan ada atau tidaknya kejadian TB relaps. Berdasarkan distribusi frekuensi, hasil penelitian ini hampir sama dengan penelitian yang dilakukan Schluger yang mendapatkan bahwa pada penderita TB perokok lebih banyak terjadi relaps dari pada penderita TB non perokok. Hal ini disebabkan karena pada perokok terjadi gangguan pada sistem pertahanan saluran napasnya sehingga rentan untuk terkena infeksi. ${ }^{11}$

\section{KESIMPULAN}

Ada perbedaan yang bermakna antara penderita TB paru perokok dan non perokok berdasarkan hasil pemeriksaan BTA awal dan adanya gejala hemoptisis.

Rata-rata usia, kejadian TB relaps dan adanya komplikasi tidak terdapat perbedaan yang bermakna antara penderita TB paru perokok dan non perokok.

\section{DAFTAR PUSTAKA}

1. Djojodibroto D. Respirologi. Jakarta: EGC; 2009. hlm. 47-51;151-68.

2. Hasan H. Buku Ajar IImu Penyakit Paru 2010. Surabaya: Departemen IImu Penyakit Paru FK Unair-RSUD Dr. Soetomo; 2010. hlm. 9-25.

3. Amin Z, Bahar A. Buku ajar ilmu penyakit dalam Jilid III. Edisi ke-5. Jakarta: Interna Publishing; 2009. hlm. 2230-9.

4. Crofton J. Tuberkulosis Klinis. Edisi ke-2. Jakarta: Widya Medika; 2002.

5. Wijaya AA. Merokok dan Tuberkulosis. Jurnal Tuberkulosis Indonesia. Vol. 82012 (diunduh 23 April 2013). Tersedia dari: URL: HYPERLINK http://ppti.info/ArsipPPTI/PPTI-Jurnal-Maret-

\section{2.pdf}

6. Aditama TY. Tuberkulosis, rokok dan perempuan. Jakarta: Balai Penerbit FKUI; 2006.

7. 7. WHO. Global Tuberculosis Report. 2012 (diunduh 21 April 2013). Tersedia dari: URL: HYPERLINK "http://www.who.int

8. Kementerian Kesehatan Republik Indonesia. Profil data kesehatan Indonesia tahun 2011.2012 (diunduh 21 April 2013). Tersedia dari: URL: HYPERLINK http://www.depkes.go.id

9. Departemen Kesehatan RI. Riset kesehatan dasar 2010.2011 (diunduh 28 Maret 2013). Tersedia dari: URL: HYPERLINK http://www.litbang.depkes.go.id/ sites/download/buku laporan/lapnas riskesdas201 0/Laporan riskesdas 2010.pdf

10. Public Health Agency of Canada. Tuberculosis (TB) and tobaccco smoking. 2010 (diunduh 21 
April 2013). Tersedia dari: URL: HYPERLINK http://www.phac-aspc.gc.ca/tbpc-latb/fa-fi/ tbtobacco-tabag-eng.php.

11. Schluger NW. The Deadly pairing of tuberculosis and smoking. world lung foundation directions.2(2). 2011 (diunduh 22 Juli 2013). Tersedia dari: URL: HYPERLINK http://www.worldlungfoundation.org/ ht/a/GetDocumentAction/i/15317

12. Hudoyo A, Agus DS, Diah H. Smoking cessation as integrated management in TB patients as smoker. 2013 (diunduh 21 April 2013). Tersedia dari: URL: HYPERLINK http://www.tbday2013.org/ pdf/TB-Day-Ritz.Karlton-30-Mrt-13.rokokTB.pdf

13. Pang $W$. The Reduction of tuberculosis risks by smoking cessation. BMC Infectious Diseases. (serial online) 2010 (diunduh 24 April 2013). Tersedia dari: URL: HYPERLINK http://www. biomedcentral.com/1471-2334/10/156.

14. Zainul M. Hubungan kebiasaan merokok dengan konversi sputum penderita TB Paru di klinik Jemadi Medan. 2009 (diunduh 23 April 2013). Tersedia dari: URL: HYPERLINK http://www.repository.usu. ac.id/bitstream/123456789/14270/1/10E00025.pdf
15. Fekih L. Effect of tobacco smoking on pulmonary tuberculosis. (serial online) 2010 (diunduh 22 Juli 2013). Tersedia dari: URL: HYPERLINK http:// www.ncbi.nlm.nih.gov/pubmed/20411820

16. Isa, M. Smoking is one of risk factor for tuberculosis. 2013 (diunduh 21 April 2013). Tersedia dari: URL: HYPERLINK http://www. tbday2013.org/pdf/Smoking is one of Risk Facto $r$ for Tuberculosis.pdf

17. Devi G. Complications of pulmonary tuberculosis. 2012 (diunduh 6 Februari 2014). Tersedia dari: URL: HYPERLINK http://www.iconceptpress.com/ download/paper/13030321070582.pdf

18. Loh LC, et al. Significant resolution of tuberculous pleural effusion on chemotherapy alone. (serial online) 2010 (diunduh 22 Juli 2013). Tersedia dari: URL: HYPERLINK http://www.rcpe.ac.uk/journal/ issue/journal 40 2/loh.pdf

19. Rodriguez D. Complication of active tuberculosis. (serial online) 2014 (diunduh 10 Februari 2014). Tersedia dari: URL: HYPERLINK http://www. everydayhealth.com/tuberculosis/complications.as $\underline{\mathrm{px}}$ 